\title{
Aqueous enzymatic extraction of coconut oil
}

\begin{abstract}
Aqueous extraction of coconut oil with various enzymes was investigated. Several enzyme preparations (cellulase, polygalacturonase, protease, and Ŭ-amylase) were used at different concentrations, $\mathrm{pH}$, and temperature values to enhance oil extraction. After the oil had been released by the enzyme reaction, it was separated by centrifugation. The results showed that an enzyme mixture at $1 \%(\mathrm{w} / \mathrm{w})$ each of cellulase, Ŭamylase, polygalacturonase, and protease at $\mathrm{pH} 7.0$ and an extraction temperature of $60^{\circ} \mathrm{C}$ represented the most effective extraction conditions with an oil yield of $73.8 \%$. Quality characteristics of the oil were as follows: moisture content, $0.11 \%$; free fatty acid, $0.051 \%$; peroxide value, 0.016 meq oxygen $/ \mathrm{kg}$; anisidine value, 0.026 ; iodine value, 8.3 ; saponification value, 260; and color, 0.6 $(\mathrm{Y}+5 \mathrm{R})$. This technique for recovering oil from fresh coconut meat with enzymes is a significant improvement in both oil yield and quality over the traditional wet process.
\end{abstract}

Keyword: Aqueous coconut oil extraction; Oil yield; Quality characteristics 